International Journal of Linguistics, Literature and Culture
Available online at https://sloap.org/journals/index.php/ijllc/
Vol. 5, No. 3, May 2019, pages: 61 70
ISSN: 2455-8028
https://doi.org/10.21744/ijllc.v5n3.646

\title{
Various Factors Contributive toward Tourist Intention in Enjoying Wellness Tourism
}

\author{
I Gusti Made Wendri a \\ I Made Bakta ${ }^{b}$ \\ Ni Wayan Sri Suprapti ${ }^{c}$ \\ I Wayan Ardika ${ }^{d}$
}

\section{Article history:}

Received: 27 January 2018

Accepted: 31 March 2019

Published: 31 May 2019

\section{Keywords:}

conventional spa;

factor analysis;

planned behavior;

special-interest tourism;

wellness tourism;

\begin{abstract}
Wellness tourism is fast growing nowadays as alternative tourism developed from conventional spa tourism into special-interest tourism. Therefore, it is interesting to study the phenomenon of this fast developing industry in Bali in order to reveal its advantage for one's wellness on the basis of the following question: What factors are contributive to the tourists' intention in enjoying wellness tourism?. This study aims to explore the factors of beliefforming the tourists' intention or interest to enjoy wellness tourism. The research adopts planned behavior theory (PBT) as its theoretical framework. The data was collected by questionnaires distributed to 100 touristrespondents accessed by purposive sampling technique. The analysis was quantitatively done using factor analysis technique as a data analytical instrument. The result of the analysis shows that there are 8 belief factors identified to form the tourists' intention in enjoying wellness tourism. These factors include: 1) the belief in spa's benefit, 2) price, 3) past experience, 4) moral obligation for health, 5) environmental awareness, 6) personal value, 7) socializing program and 8 ) health maintenance. It is hoped that this research result would provide valuable information for the development of wellness tourism in Bali.
\end{abstract}

2455-8028 ${ }^{\circledR}$ Copyright 2019. The Author. This is an open-access article under the CC BY-SA license (https://creativecommons.org/licenses/by-sa/4.0/) All rights reserved.

\footnotetext{
Author correspondence:

I Gusti Made Wendri,

Jl. Raya Kampus UNUD, Kampus Bukit Jimbaran, Badung, Bali 80361

Email address: gustimadewendri@pnb.ac.id
}

\footnotetext{
${ }^{\text {a }}$ State Polytechnic of Bali, Indonesia

${ }^{\mathrm{b}}$ Udayana University, Bali, Indonesia

${ }^{\mathrm{c}}$ Udayana University, Bali, Indonesia

${ }^{\mathrm{d}}$ Udayana University, Bali, Indonesia
} 


\section{Introduction}

Wellness tourism constitutes one sub-sector of health tourism fast developing nowadays at both national and global levels, triggered by people's growing awareness that health should become one's personal responsibility. The awareness of such health issues has motivated many people to maintain and improve their health not only when living in their home countries but also during their trip to a wellness spa. Various initiatives are taken to find alternative ways to maintain and improve their health conditions, which among others are by choosing the right trip programs providing healthy lifestyle available or offered in tourist destinations. In being so motivated, there unavoidably occurs such impact as the constant rise in the demand for wellness tourism.

Bali is well known as spa destination (Prestegard \& Skodvis, 2013) as signaled by the ever-increasing visits of foreign tourists to the island. Statistic data shows that in the period 2013-2017 the figures of foreign tourists "visits reached respectively 10.255 .134 in $2013,10.160 .945$ in 2014, 11.148 .935 in $2015,13.571 .617$ in 2016 , and 14.117.463 in 2017. The highest increase of 2.442.682 occurred in 2016 (Statistic Office of Bali Province and Bali Tourism Office, 2018). It could be ascertained that the visiting tourists would choose wellness tourism in line with their awareness of the benefit of wellness tourism which guarantees the fulfillment of their need for pleasure or enjoyment.

The fact that Bali has succeeded in achieving a position parallel to those of London, Paris, Roma, and New York as tourist destination according to Traveler's Choice Award 2017 intensifies the optimism that Bali is able to accommodate the visitors' needs during their stays in the destination through offering varied products and services that represent the attributes of the destination. It is not for nothing that Bali has been called a paradise island.

A number of studies on tourism have explained that the tourist's behavior is the basis for understanding his motivation. This motivation can be observed through the choice of programs assumed by the tourist, the choice reflecting the benefit under the tourist's concern (Koncul, 2009). Ajzen (in Ramdhani, 2011) through the theory of planned behavior explains that one's behavior serves to signal things of many benefits to the person, which very much affect his attitude leading to a certain behavior.

Then planned behavior theory explains that one's intention to behave in a certain way precedes his actual behavior. Intention with its three components that makes up one's salient belief comprises 1) one's attitude towards behavior, 2) one's attitude to social pressure affecting such behavior known as subjective norm, and 3) some control one exercises upon his behavior known as perceived behavioral control (Sutton et al., 2003). These three components make up one's (the tourist's) intention to behave or to take actions. These components of the intention are established upon one's belief on the benefit of the behavior being intended or predicted. The more positive one's belief in the behavior being intended the stronger one's intention to assume the behavior being targeted.

Backman et al., as cited by Koncul (2009), explain that motivation is related to the basic need of an individual encouraging that individual to participate in certain activities expecting that such activities will bring a certain satisfaction to him. By behavior in the context of this research is meant the behavior of enjoying wellness tourism. Mark et al., (2009), present his finding concerning 5 factors motivating the tourists to enjoy a spa in Hong Kong. The 5 factors include 1) friendship and kinship, 2) health and beauty, 3) self-reward and indulgence, 4) relaxation, and 5) relief and escape. Smith \& Puczko (2009), emphasize confirm the trend of tourists' participation in wellness spa activities for leisure and relaxation.

Based on the above background, it is interesting to study the tourists' intention to enjoy wellness tourism in Bali whereby to collect information about wellness products and services much in demand on the part of the tourists. This information will be of much use for those running the industry on the basis of which they can design products capable of fulfilling the needs of the tourists who possess certain expectations. This fulfilled, the tourists will get the expected satisfaction which makes them ready and willing to extend the information by words of the mouth to the members of their families as well as to their friends and neighbors pertaining to their experience of enjoying wellness tourism. Such satisfaction could even foster their loyalty to the destination they already visited before. In that way, the sustainability of wellness tourism could be guaranteed.

This research aims to identify the factors of belief-forming the tourists' intention to enjoy wellness tourism using factor analysis and planned behavior theory as its approach.

\section{Literature Review}

Konu (2009), defines the intention to behave as one's attempt to anticipate a future implication of certain behavior. The intention to behave, i.e. to take certain actions, is thought of as having a strong connection to a 
targeted/predicted behavior. Ahmad et al., (2016), explains that one's consciousness to assume an action for improving his health has an impact on his serious attempt under strong intention to take such action. An intention is built up by a complex of beliefs and evaluation, in both positive and negative senses, upon such action. Such beliefforming one's consciousness of the consequence of an action undertaken. If the evaluation upon the action is positive, it could strengthen his intention to do something. On the other hand, if the evaluation is negative, it can cancel one's intention to do the targeted action.

The study done by Ahmad et al., (2016), concerning the impact of using beauty products made of natural ingredients is taken as contributive to health improvement. At the same time, this study also analyses the benefit of wellness tourism believed to be capable of meeting the need for wellness dimension on the part of the tourist, namely the need for overall wealthy feeling, that is, a state of being wealthy in physical, mental, and spiritual terms (Swarbrick, 2010).

Ling (2013) studies the tourist's intention to buy green products due to the products' characteristics associated with such factors as environment, attitude, social value, self efficacy, and store image, which all serve as his behavior control belief, namely the belief that enables the tourist to do things or to behave for the targeted goal. The enabling factors from around spa environment include, for example, reasonable prices, the image of the store selling the products, and positive image of the behavior being targeted, the social impact is anticipated, and various other positive attitudes.

This present study alone, on the other hand, analyses the intention of the tourist to behave accordingly which is observable through the attitude, subjective norm, moral obligation on one's health maintenance, and one's awareness of the environmental factor, which are all contributive to solidifying the tourist's intention to enjoy wellness tourism. The social environment in which the tourist has involvement (such as family environment, marketing/promotion activity according to the wheel of wellness) all is potential to orient the tourist to regular diet program (Ellis, 2013).

\section{Planned Behavior Theory}

This theory explains the very complex human behavior which, therefore, is in need of psychological theory as the approach for its understanding which is the extension of the reasoned action theory. While on the basic expectations of planned behavior theory Ajzen (in Ramdhani, 2011) explains that there is an addition of the variable perceived behavioral control, this addition is done due to the limited capability of the theory in analyzing one's behavior lacking volitional control. The new model being developed shows the combination of the two theories which generates the theory of planned behavior. This theory places intention as a central variable. The intention is formed by such factors as the attitude to behavior, subjective norm which constitutes an individual's perception of expectations of figures of influence to him, and perceived behavior control formed on the basis of his belief upon each of these factors (Ramdhani, 2011).

The variable of intention can explain the problems faced by someone in making attempts thought of as capable of influencing his attitude to the behavior being targeted. In fact, the stronger one's intention to behave the more solid the targeted behavior becomes. One's past experience also contributes to his belief upon his attitude toward the behavior being targeted (Kim, 2009). The more familiar someone to the intended behavior the bigger the contribution to his positive attitude to repeat what is already experienced (in enjoying wellness tourism). Model of Intention Behavior in Enjoying Wellness Tourism adopted from Ramdhani (2011) and from Lindquist and Mikaele (2015) concerning moral obligation on health and environmental awareness, developed based on 2 variables in perceived behavior control.

\section{Wellness Tourism}

Ellis (2013), defines wellness tourism as a trip conducted by someone in a healthy condition to a country or a city within his own country for the purpose of obtaining services in the sector of wellness. By wellness, sector is meant the sector which provides a series of services to wellness tourists. In principle, this sector provides the overall services included in the definition of wellness cluster. The main purpose of wellness tourists is to enjoy the availability of accommodation, food, shopping, and other complementary facilities.

Wendri, I. G. M., Bakta, I. M., Suprapti, N. W. S., \& Ardika, I. W. (2019). Various factors contributive toward tourist intention in enjoying wellness tourism. International Journal of Linguistics, Literature and Culture, 5(3), 61-70. 


\section{Green Consumerism}

The concept of green tourism starts with the consumers' awareness of their dependence on the environment which is of many contributions to their positive attitude to green behavior. Green behavior, in turns, is based on beliefs that the environment contributes to human health. Through their control behavior, the tourists can modify their attitude positively into a concern with the environment-friendly issues. This public awareness of the issues of the environment got its vogue in the span of 1980-1990 (Cohen et al., 2008).

Such green consumerism behavior is, therefore, overlapping with that public awareness of the environmental issues leading in turn to their awareness of the negative impact of excessive exploitation of the environment, both physical and personal. The evolvement of this awareness is also associated with responsibility to one's own health to an extent of feeling that it becomes one's own moral responsibility for its maintenance by taking necessary preventive actions such as avoiding consumptive behavior that could devour one's health, replacing such behavior with necessary alternatives to obtain wealthy condition physically, mentally, and spiritually through wellness tourism (green traveling).

\section{Materials and Methods}

This research is based on survey method and questionnaire technique. The population of this research is foreign tourists who enjoy wellness tourism in a day spa, hotel spa, and resort spa in the two research locations under concern. Purposive sampling technique was adopted to obtain 100 tourist-respondents. Coakes et al., (2009), state that "for a quantitative study sample of 100 subjects is acceptable." The steps taken for achieving a result based on factor analysis include the following. This research determines 24 indicator variables consisting of the following: 1) 6 indicators of attitude to behavior, 2) 5 indicator for subjective norms, 3) 3 indicators of perceived control belief, 4) 5 indicators of moral obligation on health, and 5) 5 indicators of environmental awareness. These indicators constitute the predisposition factors for the tourists' motivation to enjoy wellness tourism.

In order to obtain the data of the factors forming the tourist's interest in enjoying wellness tourism, questionnaires were distributed to foreign tourists who enjoyed wellness spa in the research locations. The questionnaire comprises 24 variables that consist of attitude variable associated with the assurance that intention is there at the base of the tourists' behavior, their subjective norm, as well as at their control behavior, plus the additional variables of moral obligation on health and environmental awareness.

The variables in this research are independent variables consisting of 1) X1, namely attitude based on the belief on the part of the tourists in the consequences of enjoying wellness spa as a core product in wellness tourism;2) X2, namely belief in subjective norms, that is, the second variable contributive to the formation of intention. This variable is associated with social pressures requiring the tourists to behave in one way or another; 3) X3, namely perceived behavior control, which is the third variable contributive to intention. This variable controls the tourists' behavior in terms of the ease or difficulty likely to be faced when behaving in a certain way; 4) X4, namely the tourists' moral responsibility for their health maintenance obtainable through the values in the wellness programs under their choice which they perceive will be of benefit to them (Rodrigues et al., 2010); 5) X5, namely environment awareness variable referring to one's perception of his belief concerning the relation of his environment to the ecosystem, on the basis of which he can make a smooth decision to behave in a certain way, that is, to enjoy wellness tourism. This is closely related to the source of the tourists' motivation because the tourists' behavior is under their control.

For the measurement of attitude, subjective norms, and perceived behavior control of the respondents, they were requested to choose accordingly the statements already designed for the purpose. The measurement of the variables in the questionnaires was based on Likert's 5 scales in which each item in the questionnaires is measured in terms of responses of five categories ranging in the 1-5 scales. Of these scales, scale 1 signifies quite in disagreement, scale 2 in disagreement, scale 3 rather in disagreement, scale 4 in agreement, and scale 5 quite in an agreement. Descriptive analysis and factor analysis were applied in the data analysis. 


\section{Results and Discussions}

Table 1

Profiles of respondents based on demography

\begin{tabular}{|c|c|c|c|c|c|c|c|c|c|}
\hline No & Variable & Category & number & Percentage & No & Variable & Category & Number & Percentage \\
\hline \multirow[t]{3}{*}{1} & Gender & Female & 84 & 83.2 & 3 & Education & High School & 19 & 18.8 \\
\hline & & Male & 16 & 15.8 & & & Diploma & 16 & 15.8 \\
\hline & & Total & 100 & 100 & & & Undergraduate & 36 & 35.6 \\
\hline \multirow[t]{6}{*}{2} & Age & $21-30$ & 47 & 46.5 & & & Master/Doctorate & 29 & 28.8 \\
\hline & & $31-40$ & 26 & 25.7 & & & Total & 100 & 100 \\
\hline & & $41-50$ & 11 & 10.9 & 4 & $\begin{array}{l}\text { Country } \\
\text { of Origin }\end{array}$ & Australia & 35 & 34.7 \\
\hline & & $51-60$ & 2 & 3 & & & German & 15 & 14.9 \\
\hline & & $>60$ & 3 & 1 & & & Lain-lain & 50 & 41.4 \\
\hline & & Total & 100 & 100 & & & Total & 100 & 100 \\
\hline
\end{tabular}

Table 1 shows that the female respondents represent $83.2 \%$ of all sample respondents and, therefore, dominated the number of visits to the spa. The male respondents represent only $15.8 \%$. This trend seems to confirm the idea that women are identical to hedonistic needs. As for the male, they prefer sports and are generally reluctant to visit the spa except when accompanying their partners.

Seen in terms of ages, the respondents of 21-30 years old represent the highest frequency of visits, while those of 31- 40 years old occupy the second rank in the frequency of visit. In terms of levels of education, the respondents with graduate level represent the highest frequency of visits, while the respondents occupying the second rank were those with master's and doctor's level of education. In terms of country of origin, the respondents from Australia represent the highest in number, while those from Germany occupy the second rank. The respondents from Australia were on holiday to Bali when it was winter time in their country, while the respondents from Germany came to Bali when it was summer time in their country.

Table 2

Table of profiles of respondents based on tourist activity

\begin{tabular}{lllcl}
\hline No & Variables & Category & Number & Percentage \\
\hline \multirow{2}{*}{ Frequency Visit } & $1^{\text {st }}$ time & 42 & 41.6 \\
& Second Time & 21 & 20.8 \\
& $3^{\text {rd }}$ time & 22 & 21.8 \\
& more than 4st time & 15 & 15.8 \\
& Total & 100 & 100 \\
\hline
\end{tabular}

Table 2 shows that the tourists with the first visit to the destination represent the highest percentage, while those with the third and second visits represent the second and the third lowest in percentage. These visit frequencies indicate the tourists' positive attitude to the destination (providing wellness products and services).

\section{Research Instrument Test}

SPSS 21 test is adapted to analyze the data, and the result based on validity test shows that all loading factor values of each item are over 0.5, indicating that all items are valid. Based on reliability test it is found that the values of Cronbach's Alpha are as follows: 1) $0.785,2$ ) $0.765,3) 0.815,4) 0.815$, and 5) 0.837 , all > 0.60. Therefore, all variables can be considered reliable and the analysis can be continued (Ghozali, 2001).

The model adopted in the factor analysis is one that counts the correlations in order to know the adequacy requirement on data analysis using Barlett Test of sphericity, measure sampling adequacy (MSA), the anti-image correlation and Kaiser-Meyer-Olkin bigger than 0.5. Anti-image matrice as mentioned by Santoso (2012) as follows: a) $\mathrm{MSA}=1$, variables can be predicted without error caused by other variables, and b) MSA $>0.5$, variables still can

Wendri, I. G. M., Bakta, I. M., Suprapti, N. W. S., \& Ardika, I. W. (2019). Various factors contributive toward tourist intention in enjoying wellness tourism. International Journal of Linguistics, Literature and Culture, 5(3), 61-70. 
be predicted and can be further analyzed, and c) MSA $<0.5$, variables cannot be further analyzed or dropped from other variables.

KMO test and Barlett's test are conducted to the 24 indicators, and the result indicates the figure of 0.651. Meanwhile, the test of Barlett's of sphericity indicates the figure of 1017.128 with the value of significance of 0.5 indicating that the variables in this research can be further tested.

\section{Determination of Number of Factors}

Table 3

Total variance explained

\begin{tabular}{|l|l|l|l|l|}
\hline No & Factor & \multicolumn{2}{|c|}{$\begin{array}{l}\text { Total of Variance } \\
\text { Explained Eigen Value }\end{array}$} & Cumulative \\
\hline 1 & 1 & 5.394 & 22.475 & 22.475 \\
\hline 2 & 2 & 2.624 & 10.932 & 33.407 \\
\hline 3 & 3 & 1.090 & 8.708 & 42.115 \\
\hline 4 & 4 & 1.883 & 7.845 & 49.960 \\
\hline 5 & 5 & 1.520 & 6.554 & 56.296 \\
\hline 6 & 6 & 1.289 & 5.369 & 61.664 \\
\hline 7 & 7 & 1.153 & 3.805 & 66.469 \\
\hline 8 & 8 & 1.024 & 4.267 & 70.735 \\
\hline
\end{tabular}

Labeling the Factors

Table 4

Factors with their components

\begin{tabular}{|c|c|c|c|c|c|}
\hline Factor & Note & Indicator & Factor Loading & Variance $\%$ & Total Variance \\
\hline \multirow[t]{2}{*}{1} & $\mathrm{X} 1.1$ & $\begin{array}{l}\text { visiting spa helps me to escape from the } \\
\text { stress }\end{array}$ & 0.710 & 11.219 & 11.219 \\
\hline & $\mathrm{X} 2.1$ & $\begin{array}{l}\text { subject to the wheel of wellness as guidance } \\
\text { for consuming on a dieting program }\end{array}$ & 0.743 & & \\
\hline \multirow[t]{2}{*}{2} & X3.1 & $\begin{array}{l}\text { The availability of time make me able to } \\
\text { have holiday enjoying wellness spa } \\
\text { program, }\end{array}$ & 0.649 & 10.778 & 21.997 \\
\hline & $\mathrm{X} 3.2$ & $\begin{array}{l}\text { The availability of holistic program, as well } \\
\text { as the affordable price, make me able to } \\
\text { enjoy the spa }\end{array}$ & 0.724 & & \\
\hline 3 & X3.3 & $\begin{array}{l}\text { The culture confidence in wellness spa } \\
\text { one's has made them enjoy the wellness } \\
\text { program for the next holiday. }\end{array}$ & 0.544 & 10.016 & 32.012 \\
\hline \multirow[t]{2}{*}{3} & $\mathrm{X} 1.6$ & $\begin{array}{l}\text { Intellectual activity on wellness program } \\
\text { placing on high emphasis on environmental } \\
\text { sensitivity }\end{array}$ & 0.648 & 8.850 & 40.862 \\
\hline & $\mathrm{X} 2.5$ & $\begin{array}{l}\text { wellness spa commonly considered as many } \\
\text { dimension such as physical, psychological, } \\
\text { emotional, social, and intellectual wellness }\end{array}$ & 0.729 & & \\
\hline \multirow[t]{4}{*}{5} & $\mathrm{X} 5.1$ & $\begin{array}{l}\text { I think people in my social cycle has } \\
\text { environmental awareness }\end{array}$ & 0.614 & 8.687 & 49.549 \\
\hline & $\mathrm{X} 5.2$ & $\begin{array}{l}\text { I think spa experience is a way that is } \\
\text { considered capable of fulfilling my desire } \\
\text { to improve health and rejuvenation }\end{array}$ & 0.674 & & \\
\hline & $\mathrm{X} 5.4$ & $\begin{array}{l}\text { I Think to seek and to gain the functional } \\
\text { value on wellness tourism could improve } \\
\text { one's daily health }\end{array}$ & 0.566 & & \\
\hline & $\mathrm{X} 5.5$ & $\begin{array}{l}\text { Visiting spa is an initiative of preventing } \\
\text { and eliminating daily stress }\end{array}$ & 0.746 & & \\
\hline
\end{tabular}




\begin{tabular}{|c|c|c|c|c|c|}
\hline \multirow[t]{2}{*}{6} & X4.1 & $\begin{array}{l}\text { visiting a spa is the best solution which is } \\
\text { considered to be able to accommodate our } \\
\text { specific dietary need }\end{array}$ & 0.591 & 8.495 & 258.047 \\
\hline & X 4.2 & $\begin{array}{l}\text { One believe escape from a perceived } \\
\text { mundane environment is the best solution to } \\
\text { have on a holiday }\end{array}$ & 0.719 & & \\
\hline 7 & X2.3 & $\begin{array}{l}\text { the spa can be observed as a place for } \\
\text { socializing }\end{array}$ & 0.823 & 6.534 & 64.528 \\
\hline 8 & X 1.2 & $\begin{array}{l}\text { I think all agree visiting wellness spa is also } \\
\text { the way to rejuvenate our mind }\end{array}$ & 0.768 & 6.157 & 70.735 \\
\hline
\end{tabular}

Source: Data processing result, 2018

Factor 1. The belief on wellness spa's benefit

This factor has the eigenvalue of 5.394 with a variance contribution of 11.219 with supporting components X1.1 and X2.1 with the loading factors respectively of 0.710 and 0.743 . This factor represents the tourists' belief on the benefit of enjoying wellness tourism which contributes to their attitude to their behavior. It is explained by the indicator X1.1 that the benefit of enjoying a wellness spa is believed to be capable of relieving stress because of the opportunity to avoid the monotonous daily routines. Meanwhile, X2.1 explains that the benefit obtained from the wellness wheel marketing information can orient the tourists to choose the diet program wisely.

\section{Factor 2. Price}

This is the second of the 8 factors identified as contributive to the variable intention. It is the factor with the Eigenvalue of 5.394 with the supporting components of X3.1 and X3.2 with the loading factors respectively of 0.649 and 0.724 . It is the factor with the variance contribution of 10.778 from the total variance of 70.735 . From the range of the loading factor values, X3.2 has the highest loading factor (0.724). This indicates that the factor of price and the availability of the whole programs are perceived by the tourists as smoothing out their activity of enjoying wellness tourism. The low prices and the availability of whole programs can smooth out their goal of enjoying wellness tourist. The more positive the tourists' belief upon the accessibilities open to them, the more smooth their action to enjoy wellness tourism.

\section{Factor 3. Past Experience}

The third factor is the factor of past experience with eigenvalue of 2.624 and variance contribution of 10.016 . This factor has one supporting factor (X3.3) and the loading factor of 0.544. This factor represents the tourists' belief in enjoying wellness tourism at the time to come which, therefore, has a positive impact on their attitudes. The positive experience forming their cultural confidence of certain destinations could strengthen their intention to enjoy wellness tourism. This could strengthen the tourists' intention to repeat their pleasurable past experience. And the opposite is certainly true if their past experience is negative to a destination.

\section{Factor 4. Moral Obligation on Health}

The fourth factor with the label moral obligation on health has the eigenvalue of 1.883 with two supporting indicators, namely X1.6 and X2.6 with loading factors respectively of 0,648 and 0.729 . The loading factor X2.5 has three highest value of 0.729 . This factor has a variance contribution of 8.850 from the total variance of 70.735 . This factor explains the tourists' belief in their experience of enjoying wellness spa services which could fulfill their needs for psychological, emotional, social, and intellectual wellness as the manifestation of their moral obligation to maintain their health.

\section{Factor 5. Environmental Awareness}

Factor 5 under the label of environmental awareness has the eigenvalue of 1.520. This factor has two indicators, namely X5.1 and X5.2 with loading factors respectively of 0.614 and 0.674 , with variance contribution of 49.549 from the total variance of 70.735. The loading factor under the indicator X5.2 has a value of 0.674. This factor

Wendri, I. G. M., Bakta, I. M., Suprapti, N. W. S., \& Ardika, I. W. (2019). Various factors contributive toward tourist intention in enjoying wellness tourism. International Journal of Linguistics, Literature and Culture, 5(3), 61 -70. 
represents the tourists' belief in their environmental awareness which controls their behavior in doing things. This awareness is believed by the tourists as reflecting the dependence of human beings to the environment, including both physical and social environments, which is felt the need to maintain harmony with the environment. This factor controls the tourists' behavior toward conserving the environment, which in turn contributes to their intention to enjoy wellness tourism.

\section{Factor 6. Personal Value}

This factor with the label of personal value has two indicators, namely X4.1 and X4.2 with the loading factors respectively of 0.591 and 0.719 . This factor has the eigenvalue of 0.719 . Its variance contribution is 8.495 in which $\mathrm{X} 4.2$ possesses the highest loading factor of 0.719 / This factor indicates the tourists' belief in enjoying wellness tourism as the best solution to be conducted in the holiday occasion to come. The indicator X4.1 explains that wellness spa is believed to be capable of accommodating their specific needs pertaining to diet programs, which intensifies the tourists' intention to enjoy wellness tourism.

\section{Factor 7. Socializing Program}

The factor under the label socializing program has the eigenvalue of 1.159 and has an only indicator, namely X2.3 with the loading factor of 0.823 . This factor has the variance contribution of 6.534 from the total variance of 70.735 . The result indicates that social interaction with other visitors is believed to provide good access to knowing more people and making more friends. Having more friends is believed to be capable of gaining a higher social status.

\section{Factor 8. Health Maintenance}

Factor 8 with ninth label health maintenance has the eigenvalue of 1.024 and one indicators, namely X1.2, with the value of loading factor of 0.768 . This factor contributes to a variance value of 6.157 from the total variance of 70.735. This factor is based on the result of the evaluation done by the tourists over the consequence of doing something, i.e. of enjoying wellness tourism.

\section{Conclusion}

There have been identified 8 factors forming the tourists; intention to enjoy wellness tourism. These factors include with respective labels the following: 10 Factor 1, benefit of wellness spa; 2) Factor 2, price; 3) Factor 3, past experience; 4) Factor 4, moral obligation on health; 5) Factor 5, environmental awareness; 6) Factor 6, personal value; 7) Factor 7, socializing program; and 8) Factor 8, health maintenance. All of these factors are formed by attitudes toward behavior.

It is essential to understand the intention to behave as the source of the tourists' motivation to enjoy wellness tourism, an understanding that will help the wellness spa industry management to use the right strategy in product designing toward developing the products of the wellness program.

\section{Conflict of interest statement and funding sources}

The authors declared that they have no competing interest.

\section{Statement of authorship}

The authors have a responsibility for the conception and design of the study. The authors have approved the final article.

\section{Acknowledgments}

We acknowledge thanking the editor of IJLLC for their valuable time, support, and advice in completing the current study. 


\section{References}

Ahmad, S. N. B. B., Omar, A. B., \& Rose, R. B. (2015). Influence of Personal Values on Generation Z's Purchase Intention for Natural Beauty Products. Advances In Global Business Research Vol. 12, No. 1, ISSN: 1549-9332, 436.

Ajzen, I. (1991). The theory of planned behavior. Organizational behavior and human decision processes, 50(2), 179-211. https://doi.org/10.1016/0749-5978(91)90020-T

Bäckman, L. (1991). Recognition memory across the adult life span: The role of prior knowledge. Memory \& Cognition, 19(1), 63-71. https://doi.org/10.3758/BF03198496

BPS Propinsi Bali. Jumlah Kunjungan Wisatawan Manca Negara Ke Bali. Retrieved from https://www.google.co.id/search=BPS+Bali+Kunjungan+wisatawan+2017\&aq+BPS+Bali+kunjungan+wisatawa $\mathrm{n}+2017$

Coakes, S. J., Steed, L. G., \& Ong, C. (2009). Analysis Without Anguish Using SPSS Version 170 for windows London. UK: John Willey \& Sons.

Cohen, P. J. (2008). Set theory and the continuum hypothesis. Courier Corporation.

Ellis, S. (2013). The global wellness tourism economy 2013. Report of the Global Wellness Tourism Congress (Delhi, India). Ed. Global wellness and Spa Association, Miami, USA.

Ghozali, I. (2001). Aplikasi Analisis Multivariate Dengan Program SPSS Semarang: Badan Penerbit Universitas Dipnegoro.. 2009. Aplikasi Analisis Multivariate Dengan Program SPSS edisis keempat. Semarang: Badan Penerbit Universitas Dipnegoro.

Kim, H. (2009). Effects of Consumer Values and Past Experiences on Consumer Intention to Buy Organic Personal Care Products: An Application of the Theory of Planned Behavior. (Electronic Thesis or Dissertation). Retrieved from https://etd.ohiolink.edu/

Koncul, N. (2009). Ekonomika i turizam. Mikrorad doo, Zagreb.

Konu, H., \& Laukkanen, T. (2009). Roles of motivation factors in predicting tourists' intentions to make wellbeing holidays-A Finnish case. In ANZMAC 2009 conference proceedings.

Ling, C. Y. (2013). Consumers' purchase intention of green products: an investigation of the drivers and moderating variable. Elixir Marketing Management, 1, 14503-14509.

Mark, J. E. (Ed.). (2009). Polymer data handbook. Oxford university press.

Prestegård, I. S. (2013). Spa Pilgrimage (Master's thesis, The University of Bergen).

Ramdhani, N. (2011). Penyusunan alat pengukur berbasis Theory of Planned Behavior. Buletin Psikologi, 19(2).

Rodrigues, Á., Kastenholz, E., \& Rodrigues, A. (2010). Hiking as a relevant wellness activity-results of an exploratory study of hiking tourists in Portugal applied to a rural tourism project. Journal of Vacation Marketing, 16(4), 331-343. https://doi.org/10.1177\%2F1356766710380886

Santoso, S. (2012). Aplikasi SPSS pada Statistik Multivariat. Jakarta: Elex Media Komputindo, $219,255$.

Smith, M., \& Puczkó, L. (2008). Health and wellness tourism. Routledge.

Sutton, S., French, D. P., Hennings, S. J., Mitchell, J., Wareham, N. J., Griffin, S., ... \& Kinmonth, A. L. (2003). Eliciting salient beliefs in research on the theory of planned behaviour: The effect of question wording. Current Psychology, 22(3), 234-251. https://doi.org/10.1007/s12144-003-1019-1

Swarbrick, P. (2010). Defining wellness. Words of Wellness Vol, 3.

Wendri, I. G. M., Bakta, I. M., Suprapti, N. W. S., \& Ardika, I. W. (2019). Various factors contributive toward tourist intention in enjoying wellness tourism. International Journal of Linguistics, Literature and Culture, 5(3), 61-70. 


\section{Biography of Authors}

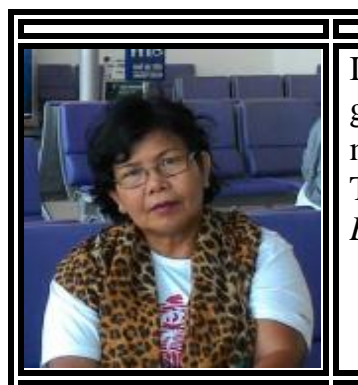

I Gusti Made Wendri is a senior lecturer in State Polytechnic of Bali, Indonesia. She graduated bachelor degree in the Faculty of Arts, Udayana University. She finished master degree in the Tourism Studies, Udayana University. She is doctoral student of Tourism Studies, Udayana University, and will be completed in 2019.

Email: gustimadewendri@pnb.ac.id

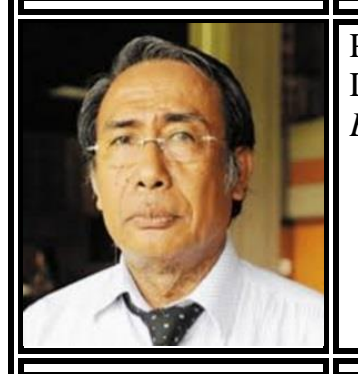

Prof. Dr. dr. I Made Bakta, Sp.PD (KHOM). is a professor in Udayana University, Denpasar, Bali, Indonesia.

Email:imadebakta@unud.ac.id

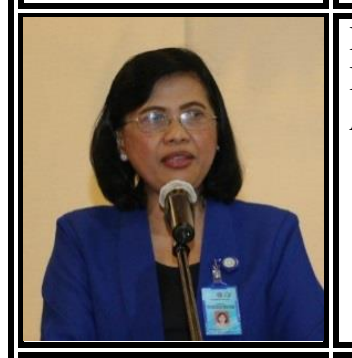

Prof. Dr. Ni Wayan Sri Suprapti, SE., Msi. is a professor in Udayana University, Denpasar, Bali, Indonesia.

Email: niwayansrisuprapti@unud.ac.id

Prof. Dr. I Wayan Ardika, M.A. is a professor in Udayana University, Denpasar, Bali,
Indonesia.
Email: iwayanardika@ unud.ac.id

